\title{
Oxytocin administration prolongs luteal function in cyclic mares
}

\author{
T. A. E. Stout ${ }^{1}$, G. E. Lamming ${ }^{2}$ and W. R. Allen ${ }^{1}$ \\ 'University of Cambridge, Department of Clinical Veterinary Medicine, Madingley Road, Cambridge CB3 OES, UK; \\ and 'University of Nottingham, School of Biological Sciences, Division of Animal Physiology, Sutton Bonington Campus, \\ Loughborough, Leicestershire LE12 5RD, UK
}

\begin{abstract}
Recent evidence indicates that, in mares, as in the domestic ruminants, oxytocin and its endometrial receptor play important roles in stimulating the pulsatile releases of prostaglandin $\mathrm{F}_{2 \alpha}$ from the endometrium that effect luteolysis. In the present experiment, continuous administration of oxytocin by subcutaneous minipump to five mares during days 8-20 after ovulation abolished luteolysis in four of them, while all four of the control mares infused similarly with saline underwent luteolysis at the expected time. When oxytocin administration began on day 10 , instead of on day 8 , after ovulation luteolysis occurred rapidly in two of the five treated mares, indicating that the development of oxytocin responsiveness begins on or about day 10 of dioestrus in cyclic mares.
\end{abstract}

\section{Introduction}

In domestic ruminants, oxytocin secreted by the corpus luteum (Wathes and Swan, 1982; Wathes et al., 1983) stimulates the pulsatile releases of $\mathrm{PGF}_{2 \alpha}$ from the endometrium that bring about cyclical luteolysis (McCracken et al., 1984). The critical factor that enables the onset of the luteolytic cascade is the upregulation of oxytocin receptors (OTRs), and the concomitant development of oxytocin responsiveness, within the endometrium (Wathes and Hamon, 1993; Wathes et al., 1996). Furthermore, the generation of luteolytic sized pulses of $\mathrm{PGF}_{2 \alpha}$ is dependent on a positive feedback relationship between $\mathrm{PGF}_{2 \alpha}$ released from the endometrium and oxytocin released by the corpus luteum (Flint and Sheldrick, 1985) and hypothalamus (Silvia et al., 1991).

In mares, the events that control luteolytic $\mathrm{PGF}_{2 \alpha}$ release are less well understood and early studies indicated that oxytocin was not involved in the luteolytic pathway (Arthur, 1975; Neely et al., 1979). However, Betteridge et al. (1985) reported that administration of oxytocin to mares in late dioestrus induced an immediate increase in peripheral plasma 13,14-dihydro-15-keto PGF $_{2 \alpha}$ (PGFM) concentrations which, in some instances, was accompanied by premature luteolysis. Subsequently, it has been demonstrated that the PGFM response to oxytocin challenge in mares is maximal at the time of expected luteolysis (Goff et al., 1987) and that this late dioestrous increase in endometrial oxytocin responsiveness is correlated with a parallel increase in endometrial oxytocin binding capacity (Sharp et al., 1997; Starbuck et al., 1998). However, the equine corpus luteum is not a source of oxytocin (Stevenson et al., 1991) and there has been considerable debate as to whether systemic oxytocin concentrations in mares fluctuate in a manner appropriate with a role for oxytocin in the luteolytic process (Burns et al., 1981; Tetzke et al., 1987; Stevenson et al., 1991). Thus,

Received 1 September 1998. evidence for the involvement of oxytocin in equine luteolysis has remained largely circumstantial.

Proof that oxytocin is instrumental in cyclical luteolysis in ruminants was provided by experiments in which disruptions of the interaction between oxytocin and its endometrial receptor caused a delay in luteolysis. Continuous systemic infusion of supra-physiological doses of oxytocin from before the normal time of cyclical OTR upregulation achieved this effect, apparently by inhibiting OTR upregulation (Flint and Sheldrick, 1985; Gilbert et al., 1989; Ayad et al., 1993). The aim of the present experiment was to test the hypothesis that oxytocin is integral to luteolysis in mares by determining whether continuous systemic administration of oxytocin to cyclic mares delays luteolysis.

\section{Materials and Methods}

\section{Animals}

The Thoroughbred mares used in this experiment were drawn from the herd maintained at grass by the Equine Fertility Unit in Newmarket. They ranged in age from 3 to 12 years and weighed between 450 and $600 \mathrm{~kg}$. They all had normal oestrous cycles, as determined by regular transrectal ultrasound examinations of their ovaries and measurements of peripheral serum progesterone concentrations (Allen and Sanderson, 1987).

\section{Experimental design}

Osmotic minipumps designed to discharge their contents at a rate of $5 \mu \mathrm{l} \mathrm{h}$-1 for 14 days (Altec $2 \mathrm{ml2}$; Charles River UK Ltd, Margate) were filled with $2.25 \mathrm{ml}$ of an $11 \mathrm{mg} \mathrm{ml}^{-1}$ solution of oxytocin (500 iu mg ${ }^{-1}$; Hoechst Roussel Veterinary Products, Wiesbaden) in $0.9 \%(\mathrm{w} / \mathrm{v})$ sodium chloride and 
$0.01 \%$ acetic acid. After local anaesthesia had been induced with $2 \%(\mathrm{w} / \mathrm{v})$ lignocaine (Lignavet Injection, C-Vet Veterinary Products, Leyland), the minipumps were inserted s.c. at the base of the neck in ten mares, five on day 8 and five on day 10 after ovulation (day 0 ), thereby producing groups in which treatment was initiated before or during the time that oxytocin responsiveness was expected to develop (between days 9 and 11 after ovulation in mares; Goff $e t$ al., 1987). Control minipumps containing vehicle only were introduced into a further four mares on day 8 and three mares on day 10 after ovulation. At 10 min intervals, from $1 \mathrm{~h}$ before to $1 \mathrm{~h}$ after insertion of each minipump, $10 \mathrm{ml}$ aliquots of jugular vein blood were collected, via a preplaced intravenous catheter, into lithium heparinized vacutainers (Becton Dickinson, Cowley, Oxford). These samples were placed on crushed ice and centrifuged at $1000 \mathrm{~g}$ for $10 \mathrm{~min}$ within $15 \mathrm{~min}$ after collection. The plasma was decanted and stored at $-20^{\circ} \mathrm{C}$ until assayed for PGFM concentrations.

The minipumps were maintained in situ for 12 days, during which time jugular vein serum samples were collected twice a day to monitor progesterone concentrations and the reproductive tracts of the mares were palpated and scanned three times a week to confirm the persistence of the corpus luteum, assess uterine tone and monitor for the occurrence of any untoward event such as a dioestrous ovulation. After removal of the minipump, serum sampling for progesterone assay was continued once a day, either until after the next ovulation in those mares that returned to oestrus spontaneously, or until day 30 . Any mare that was still in persistent dioestrus 30 days after the original ovulation was given an i.m. injection of $375 \mu \mathrm{g} \mathrm{PGF}_{2 \alpha}$ analogue, cloprostenol (Estrumate; Mallinckrodt Veterinary Ltd, Uxbridge) to induce luteolysis.

\section{Hormone assays}

13,14-dihydro 15-keto $P G F_{2 \alpha}$. Concentrations of PGFM in the plasma samples were measured using a modification of the specific, solvent-extraction radioimmunoassay described by Kaker et al. (1984) and validated for use with equine plasma by Starbuck et al. (1998). PGFM was extracted from $0.5 \mathrm{ml}$ aliquots of plasma with $3 \mathrm{ml}$ diethyl ether and measurment of the efficiency of this extraction procedure in samples of charcoal-stripped gelding plasma spiked with 80 or $190 \mathrm{pg}$ PGFM ml-1 gave values of 87.8 and $80.0 \%$. The polyclonal anti-PGFM serum (a gift from F. W. Bazer, Texas A \& M University, TX) was raised in a rabbit and was reported to show crossreactivities of $<1 \%$ with arachidonic acid, $\mathrm{PGE}_{2}, \mathrm{PGF}_{1 \alpha^{\prime}}, \mathrm{PGF}_{2 \alpha}$ and other prostanoids (Meyer et al., 1995). The minimum detection limit of the assay was $13.2 \mathrm{pg} \mathrm{ml}^{-1}$ and the mean intra- and interassay coefficients of variation were 3.3 and $13.3 \%$, respectively.

Progesterone. Progesterone concentrations in unextracted serum were measured using an amplified enzyme-linked immunoassay (AELIA: Dako Diagnostics, Ely) validated for horse serum by Allen and Sanderson (1987). The assay used a monoclonal anti-progesterone antibody coated onto the surface of the wells of a microtitre plate and showed a limit of sensitivity of $0.135 \mathrm{ng} \mathrm{ml}^{-1}$ and intra- and interassay coefficients of variation of 6 and $8 \%$, respectively.

\section{Uterine tone measurement}

Uterine tone was measured by a single operator and values were assigned on a subjective scale ranging from 0 to 4. A score of 0 indicated an extremely flaccid uterus, as might be palpated during seasonal anoestrus, while a score of 4 indicated the intense uterine tonicity that is found typically between days 18 and 30 of pregnancy (van Niekerk, 1965).

\section{Statistical analyses}

A one-tailed Fisher's exact probability test was used to determine whether the continuous systemic infusion of oxytocin influenced the number of mares that entered a prolonged dioestrous phase. In the plasma samples collected around the time of insertion of the minipump, a significant endometrial release of $\mathrm{PGF}_{2 \alpha}$ was considered to have occurred if PGFM concentrations rose rapidly by more than 2 SD above the pretreatment mean and these increased concentrations were maintained for at least two consecutive samples. Uterine tone scores recorded throughout the period when the minipump was present were pooled and the effects of the oxytocin and saline treatments were compared using Student's $t$ test.

\section{Results}

In all seven of the control mares to which saline was delivered continuously from either day $8(n=4)$ or day $10(n=3)$ after ovulation, luteolysis occurred normally during days 14-16 after ovulation (Table 1), as demonstrated by a rapid decrease in peripheral serum progesterone concentrations (Fig. 1c,d) followed, over the subsequent 3-4 days, by the ultrasonographic disappearance of the corpus luteum from the ovaries. In marked contrast, luteolysis failed to occur in four of the five mares infused with oxytocin from day 8 , and in three of the five mares infused from day 10 after ovulation. In these animals, serum progesterone concentrations remained high (Fig. 1a,b) and the primary corpus luteum remained visible in the ovaries throughout the observation period. In the one day 8 mare infused with oxytocin that did not enter prolonged dioestrus, luteolysis occurred normally on days 13 and 14. It is possible that the minipump failed to operate normally in this particular case, but the high uterine tone scores exhibited by this mare suggest otherwise. In those mares that did enter prolonged dioestrus, serum progesterone concentrations occasionally showed marked fluctuations between samples. Overall the concentrations tended to decrease slowly with time, although they were still $>1 \mathrm{ng} \mathrm{ml}^{-1}$ at the end of the experimental period on day 30 (Fig. 1a,b).

In both the mares infused with oxytocin from day 10 that failed to enter prolonged dioestrus, luteolysis occurred prematurely. In one of these mares, serum progesterone 
Table 1. Effect of continuous systemic infusion of oxytocin for 12 days, beginning on day 8 or 10 after ovulation, on luteal lifespan in cyclic mares

\begin{tabular}{llcccc}
\multirow{2}{*}{$\begin{array}{l}\text { Time of mini-pump } \\
\text { insertion (days after } \\
\text { ovulation) }\end{array}$} & & \multicolumn{3}{c}{$\begin{array}{c}\text { Number of mares showing } \\
\text { a subsequent dioestrus that was }\end{array}$} \\
\cline { 4 - 6 } 8 & Treatment & Number of mares & Prolonged ( $>30$ days) & Normal (14-16 days) & Short $(<12$ days $)$ \\
\hline \multirow{2}{*}{10} & 5 & $4^{\mathrm{a}}$ & 1 & 0 \\
& Oxytocin infusion & 4 & $0^{\mathrm{b}}$ & 4 & 0 \\
& Saline infusion (control) & 5 & 3 & 0 & 2 \\
\hline
\end{tabular}

c.bSignificantly more mares infused with oxytocin between days 8 and 20 after ovulation entered prolonged dioestrus than did those infused with saline during the same period $(P=0.048$; Fisher's exact probability test with one-tail).

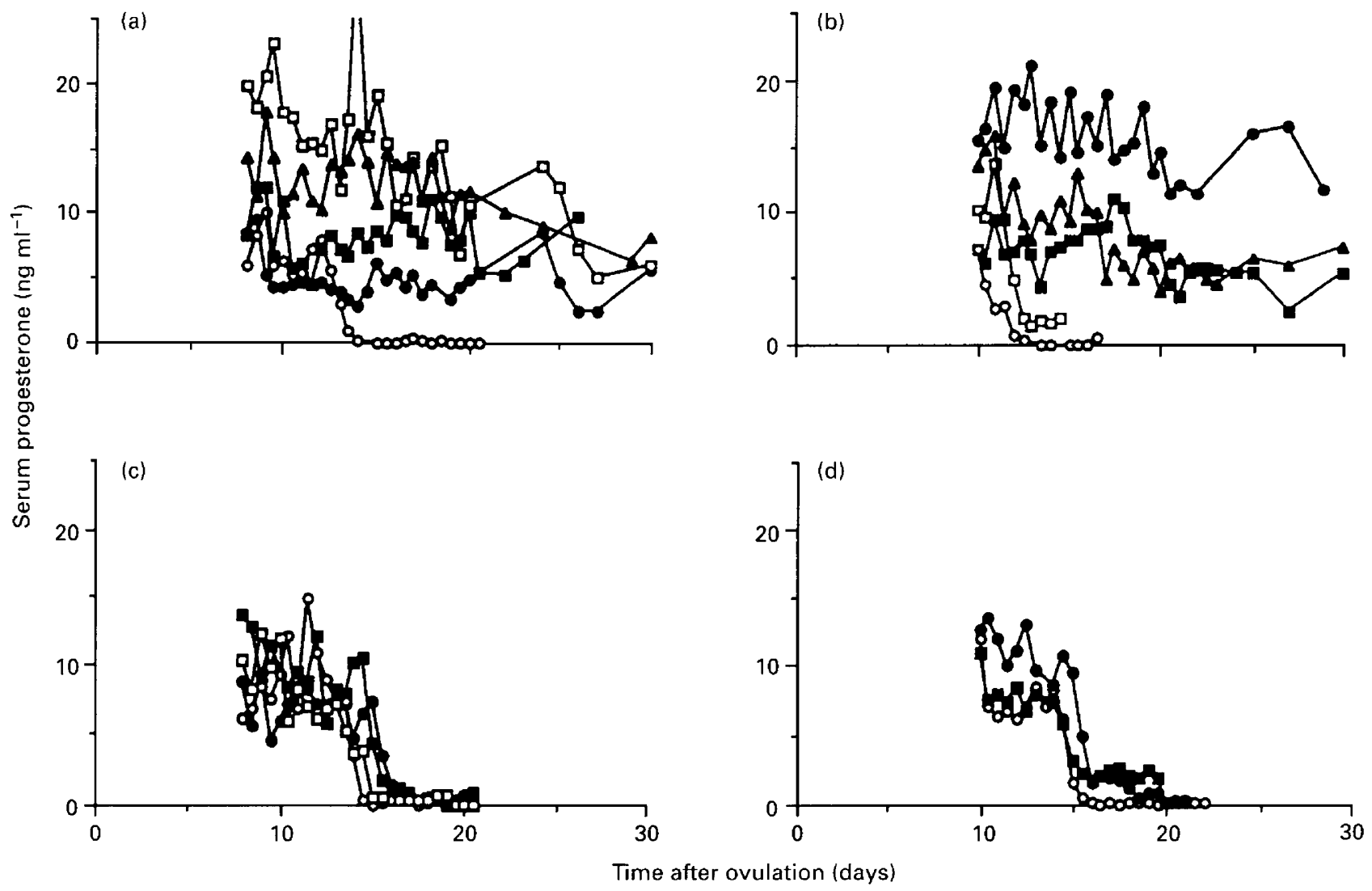

Fig. 1. Peripheral serum progesterone concentrations in individual mares infused with either $11 \mathrm{mg}^{\circ} \mathrm{oxy}$ tocin $\mathrm{ml}^{-1}(\mathrm{a}, \mathrm{b})$ or $0.9 \%(\mathrm{w} / \mathrm{v})$ saline $(c, d)$ for 12 days, beginning on day $8(a, c)$ or day $10(b, d)$ after ovulation; the solutions were delivered at an approximate rate of $5 \mu l$ $\mathrm{h}^{-1}$. All seven of the control mares infused with saline underwent normal cyclical luteolysis during days 14-16. In contrast, dioestrus was prolonged in four of five mares infused with oxytocin from day 8 and in three of five mares infused from day 10 . The other two mares infused with oxytocin from day 10 underwent luteolysis prematurely.

concentrations began to decrease within $6 \mathrm{~h}$ after insertion of the minipump and had fallen to $<1 \mathrm{ng} \mathrm{ml}^{-1}$ by $48 \mathrm{~h}$. In the other mare, a similar steep fall occurred between 24 and $48 \mathrm{~h}$ after minipump insertion but the concentrations began to increase again almost immediately owing to the ovulation of a small follicle. Plasma PGFM concentrations did not increase significantly during the $1 \mathrm{~h}$ period after minipump insertion in either of the mares that underwent premature luteolysis, nor did they in any of the other mares in the study
(Fig. 2). This finding indicated a lack of any immediate interaction between oxytocin and functional oxytocin receptors.

Uterine tone at the time of minipump insertion, as assessed subjectively on a scale of 0 to 4 , did not differ between the treatment and control groups of mares (mean \pm $\operatorname{SEM}=2.0 \pm 0.2$ versus $1.8 \pm 0.1$; Table 2 ). However, during the 12 days when the minipump was present and functional, uterine tone rose significantly in the oxytocin-treated mares 

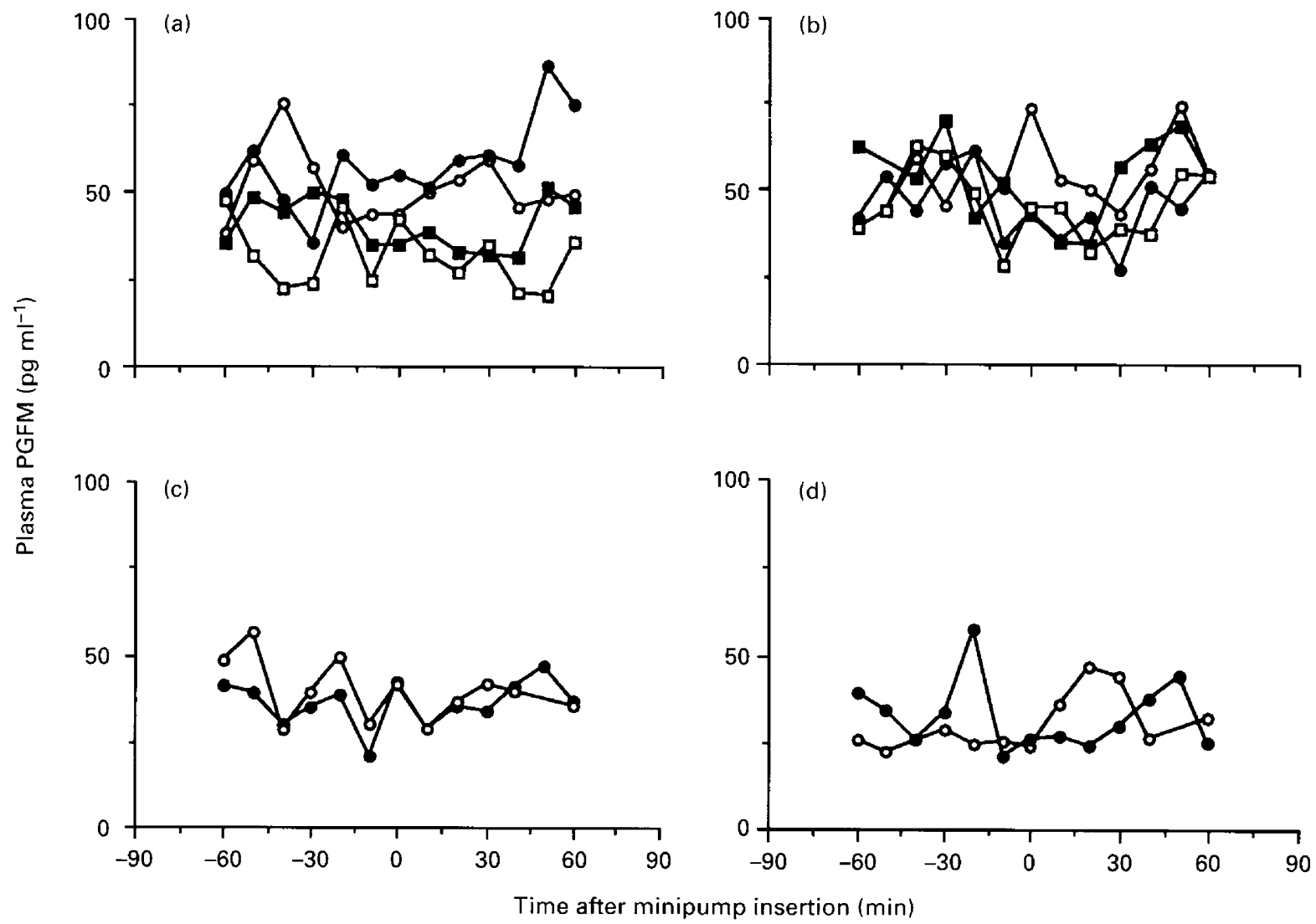

Fig. 2. Peripheral plasma concentrations of 13,14-dihydro-15-keto PGF $_{2 \alpha}$ (PGFM) in individual mares measured for $1 \mathrm{~h}$ before and $1 \mathrm{~h}$ after the s.c. insertion of osmotic minipumps (time 0 ) which contained either $11 \mathrm{mg}$ oxytocin $\mathrm{ml}^{-1}(\mathrm{a}, \mathrm{b})$ or $0.9 \%(\mathrm{w} / \mathrm{v})$ saline $(\mathrm{c}, \mathrm{d})$ on day $8(\mathrm{a}, \mathrm{c})$ or day $10(\mathrm{~b}, \mathrm{~d})$ after ovulation. There was no immediate PGFM response to minipump insertion in any of the mares.

(3.4 \pm 0.1 versus $1.6 \pm 0.2 ; P=0.0001$ ). This degree of tonicity was much greater than that encountered typically during normal dioestrus and was more reminiscent of the intense tone of early pregnancy in mares (van Niekerk, 1965; Bain, 1967).

\section{Discussion}

The finding that continuous, high-dose, systemic administration of oxytocin from day 8 after ovulation prevented luteolysis in four out of five cyclic mares supports the hypothesis that oxytocin plays an important role in cyclical luteolysis in mares. The results mirrored reports in sheep (Flint and Sheldrick, 1985; Ayad et al., 1993) and cattle (Gilbert et al,, 1989), both of which are species in which oxytocin is critical to the cyclical release of the uterine luteolysin, PGF $_{20}$. As in ewes (Flint and Sheldrick, 1985; Ayad et al., 1993), it must be assumed that the oxytocin administered to the mares caused suppression of the normal late-dioestrous cyclical increase in the number of endometrial OTRs which, in turn, prevented the oxytocin from contributing to $\mathrm{PGF}_{2 \alpha}$ release. Goff et al. (1987) reported that none of the four cycling mares to which they administered $10 \mathrm{iu}$ oxytocin as a bolus injection once a day between days 9 and 14 after ovulation returned to oestrus by day 22. Furthermore, the PGFM responses to oxytocin challenge in these mares were smaller than those in mares treated similarly on alternate days. This inhibitory effect of oxytocin on $\mathrm{PGF}_{2 \alpha}$ release has a physiological parallel in the ewe. Mann et al. (1996) reported that systemic infusion of oxytocin reduced oxytocin responsiveness in ovariectomized ewes and, from this finding, they proposed that luteal secretion of oxytocin is necessary in ewes to induce the full inhibition of OTR development, which is initiated principally by interferon $\tau$ secretion by the conceptus during the period of maternal recognition of pregnancy (Lamming et al., 1995).

In the present study, two of the five mares infused with oxytocin from day 10 after ovulation underwent premature luteolysis. Although it is possible that this premature luteolysis resulted from a pre-existing endometritis that provoked a premature release of $\mathrm{PGF}_{2 \alpha^{\prime}}$ it is much more likely to have been related to the timing of oxytocin administration with respect to development of the cyclical mechanism of luteolysis. Flint and Sheldrick (1985) found that the continuous administration of oxytocin to ewes could not rescue the corpus luteum and prolong luteal lifespan if 
Table 2. Mean ( \pm SEM) uterine tone scores measured in mares before and during the continuous systemic infusion of oxytocin or control saline via a subcutaneous osmotic minipump

\begin{tabular}{llcc}
\hline \multirow{2}{*}{$\begin{array}{l}\text { Time of minipump insertion } \\
\text { (days after ovulation) }\end{array}$} & Treatment & \multicolumn{2}{c}{ Uterine tone score * relative to the minipump } \\
\cline { 3 - 4 } & Before insertion & During insertion \\
\hline 8 & Oxytocin & $1.9 \pm 0.3^{\mathrm{a}}$ & $3.4 \pm 0.1^{\mathrm{b}}$ \\
& & $(n=4)$ & $(n=15)$ \\
& Saline & $1.7 \pm 0.1^{\mathrm{a}}$ & $1.9 \pm 0.2^{\mathrm{a}}$ \\
& & $(n=4)$ & $(n=12)$ \\
10 & Oxytocin & $2 \pm 0^{\mathrm{a}}$ & $3.6 \pm 0.1^{\mathrm{b}}$ \\
& Saline & $(n=2)$ & $(n=7)$ \\
& & $2 \pm 0^{\mathrm{a}}$ & $1.1 \pm 0.2^{\mathrm{a}}$ \\
& & $(n=2)$ & $(n=7)$ \\
\hline
\end{tabular}

*Uterine tone scored on a subjective scale of 0 (flaccid) to 4 (intensely tonic).

Uterine tone increased significantly during the period of oxytocin infusion $(P<0.01)$.

luteolysis had already commenced when oxytocin treatment began. Similarly, Kotwica et al. (1988) were unable to delay luteolysis in cattle infused continuously with oxytocin from as late as days $15-20$ after ovulation; four of eight animals treated in this manner showed an immediate PGFM response after insertion of the oxytocin minipump, thereby demonstrating that functional oxytocin receptors were already present. As a result of these and other experimental findings, Gilbert et al. (1989) proposed that continuous infusion of oxytocin can suppress OTR upregulation in ruminants only if this process has not already commenced. The absence of any significant increase in peripheral PGFM concentrations during the first hour after minipump insertion on day 10 in the two mares that underwent premature luteolysis in the present study would seem not to support the notion that OTR upregulation had already begun in these animals. However, it is possible that the $\mathrm{PGF}_{2 \alpha}$ response initiated via the small number of functional receptors present at this earliest stage of upregulation was not sufficient to cause plasma PGFM concentrations to exceed baseline fluctuations. Alternatively, the release of oxytocin from the minipump during the first hour after its insertion was insufficient to stimulate a detectable PGFM response within the brief period of frequent blood sampling.

Whether or not OTRs were already present in the two mares that underwent premature luteolysis, the temporal coincidence of minipump insertion and the beginning of the decrease in serum progesterone concentrations supports the contention that OTR upregulation starts on, or soon after, day 10 of dioestrus in cyclic mares. Goff et al. (1987) concluded that significant endometrial oxytocin responsiveness first develops at about day 11 after ovulation in mares and, therefore, it follows that, in equine pregnancy, the appropriate signal from the embryo to suppress this development of cyclical oxytocin sensitivity must begin to be released from about day 10 . Although definitive evidence that maternal recognition of pregnancy in mares depends on the inhibition of a cyclical increase in endometrial oxytocin sensitivity is still lacking, the findings of reduced endometrial OTR concentrations and attenuated responses to oxytocin challenge in pregnant mares (Goff et al., 1987; Sharp et al., 1997; Starbuck et al., 1998) strongly support the hypothesis that inhibition of OTR upregulation is an important component of the antiluteolytic mechanisms of pregnancy recognition and maintenance in equids.

The increase in uterine tone evident throughout oxytocin infusion in the present study almost certainly resulted from the prolonged, tonic contraction of the uterine smooth musculature, induced by the constant action of oxytocin on receptors within the myometrium. Although this increase in tone had no direct bearing on luteolysis, it did imply the continuing presence of functional oxytocin receptors within the myometrium throughout the period of oxytocin infusion. Since it is assumed that endometrial oxytocin receptor upregulation and activity were suppressed during this period, this finding indicates that myometrial and endometrial oxytocin receptor populations may be controlled differentially in mares.

The results of this study have provided the most conclusive evidence to date that oxytocin is involved in the luteolytic pathway in mares. Furthermore, they indicate strongly that the oxytocin responsiveness required to mediate this action of oxytocin develops on or around day 10 after ovulation.

This project was funded by the Horserace Betting Levy Board via a Veterinary Research Training Scholarship and by the Dorothy Russell Havemeyer Foundation. The authors thank M. Hunter, S. Machin and $C$. Brown for valuable assistance with the hormone assays.

\section{References}

Allen WR and Sanderson MW (1987) The value of a rapid progesterone assay (AELIA) in equine stud veterinary medicine and management Proceedings of the Ninth Bain-Fallon Memorial Lectures pp 75-82 AEVA, Sydney

Arthur GH (1975) Influence of intrauterine saline infusion upon the oestrous cycle of the mare Journal of Reproduction and Fertility Supplement 23 231-234

Ayad VJ, Parkinson TJ, Matthews EL and Wild ML (1993) Effects of pregnancy and systemic or intrauterine oxytocin infusion on the distribution of endometrial oxytocin receptors in the ewe: an autoradiographic study Journal of Endocrinology 137 423-431

Bain AM (1967) The manual diagnosis of pregnancy in the Thoroughbred mare Nezu Zealand Veterinary Journal 15 227-230

Betteridge KJ, Renard A and Goff AK (1985) Uterine prostaglandin release relative to embryo collection, transfer procedures and maintenance of the corpus luteum Equine Veterinary journal Supplement 3 25-33 
Burns PJ, Kumaresan P and Douglas RH (1981) Plasma oxytocin in cyclic mares and sexually aroused stallions Theriogenology 16 531-539

Flint APF and Sheldrick EL (1985) Continuous infusion of oxytocin prevents induction of uterine oxytocin receptor and blocks luteal regression in cyclic ewes Journal of Reproduction and Fertility 75 623-631

Gilbert CL, Lamming GE, Parkinson TJ, Flint APF and Wathes DC (1989) Oxytocin infusion from day 10 after oestrus extends the luteal phase in nonpregnant cattle Journal of Reproduction and Fertility 86 203-210

Goff AK, Pontbriand D and Sirois J (1987) Oxytocin stimulation of plasma 15-keto-13,14-dihydro prostaglandin $\mathrm{F}_{2 \mathrm{x}}$ during the oestrous cycle and early pregnancy in the mare Journal of Reproduction and Fertility Supplement 35 253-260

Kaker ML, Murray RD and Dobson H (1984) Plasma hormone changes in cows during induced or spontaneous calvings and the early post-partum period Veterinary Record $115378-382$

Kotwica J, Schams D, Meyer HHD and Mittermeier T (1988) Effect of continuous infusion of oxytocin on length of the oestrous cycle and luteolysis in cattle Joumal of Reproduction and Fertility 83 287-294

Lamming GE, Wathes DC, Flint APF, Payne JH, Stevenson KR and Vallet JL (1995) Local action of trophoblast interferons in suppression of the development of oxytocin and oestradiol receptors in ovine endometrium Journal of Reproduction and Fertility 105 165-175

McCracken JA, Schramm W and Okulicz WC (1984) Hormone receptor control of pulsatile secretion of $\mathrm{PGF}_{2 a}$ from the ovine uterus during luteolysis and its abrogation in early pregnancy Animal Reproduction Science 731-55

Mann GE, Payne JH and Lamming GE (1996) The effect of oxytocin and oestradiol on the action of conceptus secretory protein in progesteronetreated ovariectomised ewes Journal of Endocrinology 150 473-478

Meyer MD, Hansen PJ, Thatcher WW, Drost M and Badinga L (1995) Extension of corpus luteum lifespan and reduction of uterine secretion of prostaglandin $\mathrm{F}_{2 x}$ of cows in response to recombinant interferon $\alpha$ fournal of Dairy Science 78 1921-1931

Neely DP, Stabenfeldt GH and Sauter CL (1979) The effect of exogenous oxytocin on luteal function in mares Journal of Reproduction and Fertility $\mathbf{5 5}$ 303-308

Sharp DC, Thatcher M-J, Salute ME and Fuchs AR (1997) Relationship between endometrial oxytocin receptors and oxytocin induced prostaglandin $\mathrm{F}_{2 \alpha}$ release during the oestrous cycle and early pregnancy in pony mares Journal of Reproduction and Fertility 109 137-144

Silvia WJ, Lewis GS, McCracken JA, Thatcher WW and Wilson L (1991) Hormonal regulation of uterine secretion of $\mathrm{PGF}_{2 \pi}$ during luteolysis in ruminants Biology of Reproduction $45655-663$

Starbuck GR, Stout TAE, Lamming GE, Allen WR and Flint APF (1998) Endometrial oxytocin receptor and uterine prostaglandin secretion in mares during the oestrous cycle and early pregnancy Journal of Reproduction and Fertility 113 173-179

Stevenson KR, Parkinson TJ and Wathes DC (1991) Measurement of oxytocin concentrations in plasma and ovarian extracts during the oestrous cycle of mares Journal of Reproduction and Fertitity 93 437-441

Tetzke TA, Ismail S, Mikuckis G and Evans JW (1987) Patterns of oxytocin secretion during the oestrous cycle of the mare Journal of Reproduction and Fertilify Supplement 35 245-252

van Niekerk CH (1965) Early clinical diagnosis of pregnancy in mares Journal of the South African Veterinary Medicine Association 36 61-69

Wathes DC and Hamon M (1993) Localisation of oestradiol, progesterone and oxytocin receptors in the uterus during the oestrous cycle and early pregnancy of the ewe Journal of Endocrinology $138479-491$

Wathes DC and Swann RW (1982) Is oxytocin an ovarian hormone? Nature, London 297 225-227

Wathes DC, Swann RQ, Birkett SD, Porter DG and Pickering BT (1983) Characterisation of oxytocin, vasopressin and neurophysin from the bovine corpus luteum Endocrinology 113 693-698

Wathes DC, Mann GE, Payne JH, Riley PR, Stevenson KR and Lamming GE (1996) Regulation of oxytocin, oestradiol and progesterone receptor concentrations in different uterine regions by oestradiol, progesterone and oxytocin in ovariectomised ewes Journal of Endocrinology 151 375-393 